\title{
Spiritual Attachment: A Search to Seek Treasure Troves in Life with Reference to Paulo Coelho's The Alchemist
}

\author{
K.S.Priya \\ Assistant Professor of English \\ Science and Humanities \\ Amrita College of Engineering and Technology \\ Amritagiri, Nagercoil, Tamil Nadu, India \\ ksp.mphil@gmail.com
}

K.Rathinam@Shanmugasundarie

Assistant Professor of English

Science and Humanities

Amrita College of Engineering and Technology

Amritagiri, Nagercoil, Tamil Nadu, India

rathisundarie9993@gmail.com

\begin{abstract}
The purpose of this paper is to highlight the spiritual quest attaches one's soul with divine nature with reference to Paulo Coelho's The Alchemist. The personal calling is something to be addressed with care and to be dealt seriously and this is evident in The Alchemist. According to this paper, the whole world has a single great truth. Thus the paper tries to infer the truth with the help of the tool namely inner (spiritual quest). Along with the inner quest, the outer world is
\end{abstract}


connected and thus Paulo Coelho observes everything in and around and comes out with a dogma of life which made his book one of the best sellers. Every living organism on earth has a search and to find what is the search one has to observe inner self as well as outer world. This paper tries to prove that how the universe supports one's effort to succeed.

Keywords: Spiritual Quest, Calling, Truth, Inner Self, Observe, And Attachment.

Introduction

Paulo Coelho is a Brazilian lyricist and novelist. He is the recipient of numerous international awards; amongst them is the Crystal Award by the World Economic Forum. Originally, The Alchemist was written in Portuguese and later it has been translated into 67 languages and edited in more than 150 countries. This book is an international best seller. . According to the official website of $\mathrm{BBC}$, “This novel is recorded as the $94^{\text {th }}$ in the BBC's Big Read Top 100 in April 2003” (Top 100). Every book of Paulo Coelho is an answer to his inner questions and doubts and so, is 'The Alchemist'. His pilgrimage to Santiago de Composela is a turning point for him to try his hand in The Alchemist. He dedicated most of his life to penetrate the secrets of the universe. After the pilgrimage, he gets to know the mysteries of the universe; followed the omens; paid attention to miracles. He felt that these have close kinship with our life. Spiritual Attachment

The Alchemist tells the story of a young shepherd named Santiago who is in search of a treasure beyond his wildest dreams. The shepherd Santiago roams around with his flock of sheep each day with no purpose but to travel, a desire he yearns always. Ever since he had been a child, he wanted to know the world and that is important to him than knowing God. As a result, he 
chooses his path 'a travel to explore the world and experience reality'. His dreams made him realize his destiny. He believes that dreams are the language in which the universe speaks. Alan Riding in an article "Paulo Coelho: Writing in a Global Language" written in The New York Times opines: “The key that unlocked this writer's dream was 'The Alchemist', his inspirational fable about a Spanish shepherd who travels to the pyramids of Egypt in search of a treasure and instead find his 'personal legend' or destiny".

Paulo Coelho's spiritual quest made him explore the hidden side of universe, which he never thought to look upon. He is a catholic whose religion taught him discipline and collective worship to reach God. He does not believe in these objectives. Still he believes in having a wideopen mind to learn and discover the secrets of life. He considers omens as strange, individual language that guides you towards your destiny. They are not logical. But talk to your heart directly. He insists us to be aware of your personal calling. When a person wants something in life, his intense desire to achieve fulfills his destiny. He calls this desire a personal legend. He remarks:

A force appears to be negative, but actually shows you how to realize your destiny. It prepares your spirit and your will, because there is one great truth on this planet: whoever you are, or whatever it is that you do, when you really want something, it's because that desire originated in the soul of the universe. It's your mission on earth. (TA 20-21)

Ostensibly, here we find Santiago exerting to seek his destination. From his home in Spain, he journeys to the Egyptian desert. His encounter with the Alchemist has shown a way for his pursuit of treasure. He faced bout of despair on the way of his travel. His great deal of expectancy in transforming his dream into reality unfortunately gave him the worst experience at first. Each day he experienced a new life. But the very hope sped up his pursuance. His hardships 
and agonies are the only task that created him to watch the universe with sort of sense. He let his life proceed in its own direction towards its own fate. David E. Roberts believes that, "The freedom which people have in making choices is not only related to how free they are, is there anybody else who influences them or not. Freedom means that we have a hand in making ourselves what we are to become" (TA 74). Thus Santiago's quest with staunch belief that he will find the treasure made him finally reach his ultimate destination.

Paulo Coelho is a good observer. He observes and pays importance to each and every happening around him. The protagonist of the novel Santiago is the portrayal of himself. The shepherd observes human life and experiences. The moment his meeting with the Englishman taught him there must be always a search in life. His dilemma; his choice; his desire in finding the treasure made him act imbecile. He makes considerable tussle with his inner-self questioning whether to pursue his search or not. In the end, he gets an answer by experiencing his life in different streams. Soren Kierkegaard aptly states, "Philosophy is perfectly right in saying that life must be understood backward. But then one forgets the other clause-that it must be lived forward (TA 263).

Santiago worked in a crystal shop for one year learning much about life and about his personal legend. The days he spends in the crystal shop made him realize what life is all about. Through the words of the owner in the crystal shop, there are some patches we find in regard to the faith of Islam. His longing to visit Mecca at least once his lifetime made Santiago think all religion finally reaches one flame of light. Be it Christians or Islamists, people have a chase with time to get along their journey's end. Santiago's love with Fatima feels him that love never keeps a man from pursuing his destiny. Before reaching almost to the pyramids Santiago and the Alchemist are attacked by a warring tribe. The Alchemist listens to his heart intently; he feels the 
soul of the world and becomes a part of it. He trusts his inner awakening that made him to turn into the wind. He remarks: "When you are loved, you can do anything in creation. When you are loved, there's no need at all to understand what's happening, because everything happens within you, and even men can turn themselves into the wind" (TA 140).

The Alchemist made Santiago realize that a person's intense belief is capable of transforming everything one desire in life. His search for treasure teaches us the way of perceiving issues. Paulo Coelho reveals life as a gifted one. People should not belittle life. The things we take for granted are somewhere designed by someone for a particular cause; may be a supreme force agreeably. The author insists us that at any cost one should never give up hope.

\section{Conclusion}

In Paulo Coelho's dictionary, we couldn't find a word 'Impossible'. He proves it so in his writings. On reading 'The Alchemist' we will be taken to a magical world filled with dreams, magic and omen. By penetrating deeply into the novel we could feel the character Santiago is the manikin of perseverance striving to climb the rung of success. We bury ourselves in Santiago to find us. 'When you want something, the universe conspires to help you achieve it', is often reiterated by Paulo Coelho in this novel. Our mind is blocked by practice of infidelity and societal circumstances. It has become so small. There arises a spark in the life of everyone by sheer happenstance. One who takes the flame and find their own way will reach their destination. Every creation on this earth must have a search in something. That search takes you to unlimited possibilities in life. Life is important. However, search in life is very important and it is well instilled to us by reading this novel. Perhaps, Paulo Coelho has also tried to incubate this idea to the readers. 


\section{Work Cited}

Coelho, Paulo. The Alchemist. London: Harper Collins Publishers, 1988. Print.

Kierkegaard, Soren. "The Present Age". A Kierkegaard Anthology. New Jersey: Princeton University Press, 1973. 258-269. Print.

Roberts, David E. Kierkegaard. Existentialism \& Religious Belief. New York: Oxford University Press, 1957.(61-142). Print.

Official Site of BBC. The Big Read Top 100. April 2003.24. December 2007. <http://www.bbc.co.uk/arts/bigread/top100_2.Shtml>.Web.

Riding, Alan. Paulo Coelho: Writing in a Global Language. The New York Times.30 Aug, 2005.

<www.nytimes.com/2005/08/30/books/paulo-coelho-wtriting-in-a-global-language.html>. Web. 